\title{
Miten maahanmuutto ja suomalaisuus näyttäytyvät tulevaisuuden terveys- ja hyvinvointitutkimuksissa?
}

\section{SHADIA RASK}

\section{Puheenvuoro väestön moninaisuudesta ja suomalaisuuden määrittelystä}

"The problem of the twentieth century is the problem of the colour line, the question as to how far differences of race, which show themselves chiefly in the colour of the skin and the texture of the hair, are going to be made, hereafter, the basis of denying to over half of the world the right of sharing to their utmost ability the opportunities and privileges of modern society.” (1)

\section{JOHDANTO}

Tämä puheenvuoro kuvaa Suomen väestön moninaisuutta ja suomalaisuuden määrittelyä värillisen suomalaisen maahanmuuttotutkijan silmin. Kirjoitus on syntynyt tutkijavaihdossa University of Pennsylvaniassa keväällä 2017. Tuttavallisemmin tunnettu Pennin yliopisto sijaitsee Philadelphiassa, jossa ulkomailla syntyneiden osuus on 13 prosenttia väestöstä. Osuus on samansuuruinen Helsingin väestössä ja myös Yhdysvalloissa kokonaisuudessaan. Amerikkalainen maahanmuuttokonteksti eroaa kuitenkin monin tavoin Suomesta muun muassa maahanmuuton pitkän historian, tulijoiden suuren määrän ja erilaisen valikoituneisuuden vuoksi. Maahanmuuttokeskustelussa näkyy se, että Yhdysvallat on maahan muuttaneiden perustama maa. Yhdysvallat poikkeaa Suomesta myös siinä, että maassa syntyneet saavat automaattisesti Yhdysvaltain kansalaisuuden.

Yhdysvalloissa puhutaankin maahanmuuttajuuden sijaan useimmiten rodusta. Asuinalueiden eriytyminen rodun ja sosioekonomisen aseman mukaan on yleistä Yhdysvalloissa. Philadelphiassa on absoluuttisen määrän perusteella maan kolmanneksi suurin afroamerikkalainen väestö. Yliopiston viereinen West Philadelphian lähiö on poikkeuksellisen moninainen naapurusto, jossa afroamerikkalaisten osuus on 75 prosenttia. Silti kävelymatkan päässä olevan Pennin kandiopiskelijoista vain seitsemän prosenttia on afroamerikkalaisia (2). Jatko-opiskelijoissa osuus putoaa viiteen prosenttiin, ja opetushenkilökunnassa afroamerikkalaisten osuus on alle neljä prosenttia. Tämä on vain yksi osoitus syvästä eriarvoisuudesta amerikkalaisessa yhteiskunnassa. Luvut tekevät osaltaan näkyväksi rodun merkityksen mahdollisuuksien määrittelijänä ja afroamerikkalaisen väestön ylisukupolvisen huono-osaisuuden. Näistä syistä "black lives matter" ja "stop racial profiling" -liikehdinnät ovat näkyvästi läsnä West Philadelphiassa. Tässä ympäristössä syntyi uusia ajatuksia suomalaisuudesta ja kotimaisesta maahanmuuttokeskustelusta. Laitan puheenvuorossa myös oman ihoni peliin. Tämä on olennaista, sillä yli 100 vuotta Waltersin ym. kirjoituksen jälkeen, yhteiskunnan kipeimmät ja ajankohtaisimmat kysymykset kietoutuvat edelleen väriviivan ympärille.

\section{AJATUKSIA ROTUJAOTTELUSTA YHDYSVALLOISSA}

Yhteiskunta Yhdysvalloissa on hyvin rotutietoinen ja rodun mukaan luokiteltu. Rotuajatteluun sekoittuu yhä vanhentuneita perimää ja biologiaa painottavia rotuoppeja, vaikka rodut ymmärretään sosiaalisesti ja kulttuurisesti tuotettuina kategorioina, joihin liittyy erityisesti vallan asetelma (3). Amerikkalainen rotuajattelu on kehittynyt ja muuttunut eri aikakausina. Orjuuden oikeuttava rasistinen ajattelu on tehnyt tilaa diskurssille rotujen välisestä samankaltaisuudesta ja ystävyydestä. Ensimmäisen ajattelutavan kritiikin ymmärtää intuitiivisesti, mutta myös jälkimmäistä näkökulmaa on kritisoitu siitä, että se tekee näkymättömäksi vuosisatoja jatkuneen rakenteellisen 
rasismin ja siitä johtuvan eriarvoisuuden (4). On vielä näkemättä, minkälainen vaikutus tämänhetkisellä maahanmuutolla, ja erityisesti Aasiasta ja Latinalaisesta Amerikasta polveutuvalla väestöllä, tulee olemaan perinteiseen mustavalkoiseen rotuajatteluun (5).

Tietoa rodusta käytetään yleisesti yhdysvaltalaisissa tutkimuksissa, koska rotuluokittelu on amerikkalainen normi; kysymys rodusta nähdään yksinkertaisena ja helposti mitattavana; rodun ajatellaan olevan vakaa käsite ja rodut ennustavat terveyseroja (6). Todellisuudessa rodun käsite ei ole yksinkertainen, eivätkä esimerkiksi Yhdysvaltoihin muuttaneet osaa automaattisesti valita rotuaan. Väestölaskentaviraston rotuluokat ovat myös muuttuneet usein. Ajankohtaisia kysymyksiä ovat oman luokan perustaminen "Hispanic" -ryhmälle, joka nykyisellään nähdään etnisyytenä, sekä Lähi-idästä ja Pohjois-Afrikasta polveutuvien erottaminen valkoisesta luokasta omaksi rotuluokakseen. Nykyisellään juuret Egyptissä luokitellaan kuuluvaksi valkoiseen rotuun, kun taas juuret Sudanissa kuuluvat mustaan rotuun. Tosielämässä maiden välinen raja on kolonialismin seurauksena vedetty viiva ja keinotekoisen roturajan yli elää monia väestöryhmiä.

Tilastoluokitukset ovat toisin sanoen rodullistettuja (3). Rodullistamisella tarkoitetaan niitä oletuksia, stereotypioita ja ennakkoluuloja, joita ihmisiin liitetään esimerkiksi ihonvärin vuoksi. Rodullistaminen edeltää rasismia ja niiden välillä on kiinteä yhteys; molemmat tuottavat ja ylläpitävät rotujärjestelmää ja siihen liittyvää etnisten ryhmien hierarkiaa (7). Muuttujana rotu mittaakin yhteiskunnan langettamaa identiteettiä ja identiteetistä johtuvaa altistumista tietynlaisille yhteiskunnallisille rasitteille, kuten rasismille (6). Rotu ei ole yksilön ominaispiirre, vaan tilannesidonnainen muuttuja. Yhdysvalloissa toiseutta tuotetaan jakamalla ihmiset rotuluokkiin, Suomessa taas määrittelemällä ihmisiä maahanmuuttajiksi.

\section{AJATUKSIA VÄESTÖTUTKIMUKSESTA SUOMESSA}

Maahanmuutto Suomeen on yleistynyt vasta viimeisten vuosikymmenten aikana, mutta ulkomailta Suomeen muuttaneiden ihmisten määrä on lyhyessä ajassa selvästi kasvanut. Lisääntynyttä maahanmuuttoa on seurannut maahanmuuton suosion kasvu kotimaisten tutkimusten kohteena
(8). Tutkimusten lähtökohdat ovat olleet vilpittömät: eriarvoisuuteen ei voida puuttua, ellei ensin osoiteta sen olemassaoloa. Lisääntynyt tutkimustieto onkin pääosin otettu vastaan tarpeellisena ja kiitellen. Tilastoinnissa on keskitytty ulkomaalaisuuden tunnistamiseen ja erilaisten muuttujien (kuten syntymämaan, kansalaisuuden ja äidinkielen) rajoitteisiin. Näistä lähtökohdista vuonna 2012 otettiin käyttöön syntyperämuuttuja, joka määritellään henkilön vanhempien syntymämaan perusteella (9). Käytäntö on samansuuntainen muissa Pohjoismaissa ja Alankomaassa (10).

Maahanmuuttajuuden tilastointia on myös ajoittain kritisoitu, ja väestötutkimusten ulkopuolella maahanmuuttajuus on kuvattu sosiaaliseksi kategoriaksi $(11,12)$. Kritiikin kohteena on ollut erityisesti se, että ulkomaalaistaustaiseen väestöön lasketaan kuuluvaksi myös Suomessa syntyneet henkilöt, jos heidän molemmat vanhempansa (tai ainoa tiedossa oleva vanhempi) ovat syntyneet ulkomailla (13). Tilastoluokitusten tiedostetaan eroavan ihmisten omasta määrittelystä ja identiteetistä (14). Silti vähemmälle huomiolle on jäänyt se, että tutkijoiden käsitteet vaikuttavat yksilöiden identiteetteihin ja myös tutkijoiden nimeämisiin liittyy rodullistamisen vaara (15). Luokitteluilla on seurauksia yksilöiden elämään, sillä todellisina pidetyt asiat ovat todellisia seurauksiltaan (16).

\section{KÄSITTEIDEN YLL̈PITÄMÄ TOISEUS}

Monet kotimaiset tutkimukset aiheellisesti korostavat maahan muuttaneen väestön heterogeenisyyttä. Tiedetään esimerkiksi, että osa terveyseroista maahan muuttaneiden ryhmien ja koko väestön välillä katoavat, kun maahan muuttanutta väestöä tarkastellaan yhtenä kokonaisuutena (17). Toisaalta eri väestöryhmät nähdään helposti rajattuina porukoina, jotka koostuvat sisäisesti samanlaisista ihmisistä, joita on mielekästä analysoida yhtenä tietyntaustaisena joukkona (18). Maahan muuttaminen ei kuitenkaan tee ihmisistä maahanmuuttajia, ellei heitä sellaisiksi määritellä. Maahan muuttaminen tulisi nähdä yhtenä asiana ihmisen taustassa, ei ihmisen ensisijaisena piirteenä, jonka perusteella hänet voi luokitella kuuluvaksi yhtenäiseen ryhmään. Vertailuasetelmiin perustuvissa tutkimuksissa on enenevässä määrin siirrytty käyttämään valtaväestön sijaan käsitettä koko väestö, jotta vältettäisiin mielikuvat yhdestä yhtenäisestä valtaväestöstä. Huomaamatta 
kuitenkin osa ihmisistä on tullut siirretyksi paitsi vallan, myös koko väestön ulkopuolelle.

Esimerkiksi Maahanmuuttajien terveys- ja hyvinvointitutkimuksessa (Maamu) tarkasteltiin Suomeen muuttaneita ja Venäjällä, Somaliassa, Irakissa tai Iranissa syntyneitä ihmisiä (19). Raportoinnissa käytettiin ilmaisuja venäläistaustainen, somalialaistaustainen ja kurditaustainen, koska pitkään Suomessa asuneet tutkittavat eivät halunneet identifioitua maahanmuuttajiksi ja kokivat käsitteen leimaavana. Ajattelimme, että "-taustaisuus" tavoittaisi ulkomaalaisen syntymämaan, mutta jättäisi tilaa suomalaistumiselle. Useissa Maamu-tutkimusta seuranneissa tutkimuksissa ulkomaalaistaustaisiksi ja (toisen polven) maahanmuuttajiksi on lukeutunut myös Suomessa syntyneet henkilöt $(17,20)$. Kouluterveyskyselyssä jo yksi muualla kuin Suomessa syntynyt vanhempi siirsi lapsen nk. valtaväestön ulkopuolelle (21). Huomionarvoista on, että Maamu-tutkimuksen ulkomailla syntyneet pitkään Suomessa asuneet kokivat maahanmuuttaja-sanan leimaavaksi, mutta silti kutsumme heidän Suomessa syntyneitä lapsiaan (toisen sukupolven) maahanmuuttajiksi.

Ulkosuomalaisiin viitataan puolestaan usein esimerkiksi ruotsinsuomalaisina tai amerikansuomalaisina. Side entisen kotimaan ja maasta muuttaneiden välillä on ollut tärkeää paitsi Suomelle myös monelle Suomesta muuttaneelle. Toisaalta Ruotsissa suomalaisuus on useammin liitetty heikkoon sosioekonomiseen asemaan, jolloin suomalaisuutta ei aina ole haluttu korostaa. Philadelphiassa havaitsin, että amerikkalaiset ovat innokkaita tuomaan esiin omia kaukaisia sukujuuriaan. Amerikanitalialaiseksi esittäytyvät eivät kuitenkaan puhu italiaa tai ole käyneet Italiassa, vaan heidän edesmenneet iso-isovanhempansa ovat syntyneet Italiassa. Italialaisuus on vaalittu ja ennen kaikkea itse valittu positiivinen identiteetin lisä, jolla höystetään omaa amerikkalaisuutta. Mitä lähempänä transkulttuuriset juuret ovat ja mitä enemmän niiden koetaan kyseenalaistavan amerikkalaisuutta, sitä vähemmän näitä juuria halutaan korostaa. Tämä kuvastuu Bayeté Ross Smithin tuottamassa videossa (22), jossa yksi haastatelluista kertoo: "I don't like the term Indian-American. I don't like the hyphenation, because I am American." Miten käsitteet kuten suomensomalit tai suomenkurdit koetaan tänä päivänä? Entä miten ne koetaan tulevaisuudessa? Voiko esimerkiksi somalialaiset juuret olla muutaman sukupolven päästä itse valittu positiivinen identiteetin lisä, jolla höystetään omaa suomalaisuutta? Tänä päivänä 40 prosenttia Suomen somaleista on Suomen kansalaisia, mutta heidän kokemuksissaan suomalainen yhteiskunta näkee vain heidän juurensa Somaliassa (23). Tämän voi ymmärtää osasyyksi sille, että kaikki Suomessa syntyneetkään eivät koe itseään suomalaiseksi (13).

\section{KOLMANNEN SUKUPOLVEN KYSYMYS}

Kolmannen sukupolven määrittelyä ei vielä ole pidetty ajankohtaisena Suomessa, sillä ns. toiselle sukupolvelle on syntynyt vasta alle 100 lasta. Mielestäni on jo aika miettiä, miten suomalaisuuden ja ulkomaalaisen syntyperän käsitteellistäminen tulee muuttumaan, kun Suomen väestön näkyvät transkulttuuriset juuret läpäisevät monia sukupolvia. Yksi tulevaisuudenskenaario on raportoida koettua etnisyyttä, johon liittyy monenlaista huomioitavaa. Tiedetään, että kokemukset identiteetistä ja etnisyydestä ovat tilannesidonnaisia, ajassa muuttuvia ja ulkoisille vaikutteille alttiita. Muuttujana koettua etnisyyttä lähestytään usein binäärisenä (joko-tai), kun todellisuudessa kokemukset kuulumisesta ja identiteetistä ovat harvoin näin mustavalkoisia (24). Koettu etnisyys liittyy myös keskeisesti värillisyyteen, sillä erityisesti poikkeavan ihonvärin tiedetään tuottavan kokemuksia suomalaisuuden kyseenalaistamisesta (15). Kuvaavaa on, että esimerkiksi Isossa-Britanniassa termi etninen vähemmistö viittaa useimmiten ei-valkoisiin vähemmistöryhmiin, jotka polveutuvat muista kuin eurooppalaisista maista (25).

Toinen tulevaisuudenskenaario on ulkomaalaistaustaisuuden raportoiminen isovanhempien syntymämaan perusteella. Näin tehdään jo Norjassa, jossa norjalaiset on jaettu 30 luokkaan oman, heidän vanhempiensa sekä neljän isovanhemman syntymämaiden perusteella (26). Mutta mikä määrä ulkomaalaistaustaisuutta on tarpeeksi paljon, että sen ajatellaan vaikuttavan yksilön elinoloihin, koulutukseen ja uravalintoihin? Jos ajattelemme, että ulkomaalaistaustaisuus ei ole yksilön ominaispiirre, vaan yhteiskunnalliseen kontekstiin sidottu muuttuja, ulkomaalaistaustaisuuden vaikutus riippuu pitkälti yksilön sijoittumisesta väriviivalla. Värillisenä suomalaisena tiedän, miten oletus suomalaisuudesta 
perustuu ihonväriin. Omat lapseni, jotka ovat vihreäsilmäisiä ja vaaleaihoisia, hyväksytään kyseenalaistamatta suomalaisiksi. Tutkimustiedon valossa heidät nähtäisiin useammin sudanilaistaustaisina, jos he olisivat perineet minulta tummempia piirteitä tai isäni afrotukan. Arkipäiväisessä yhteiskunnassamme väriviiva siis määrittelee, keitä etninen tausta seuraa ja keitä ei. Tutkimusmaailmassa määrittelyn tekee tutkija.

\section{TEORIAN KESKEISYYS JA KRIITTISYYS}

Tutkimustiedon sosiaalinen rakentuminen on usein ohitettu terveystieteissä (27). Tutkimustieto ei kuitenkaan synny irrallaan sosiaalisesta kontekstista, vaan on monin tavoin ennakkoluulojemme värittämää. Teoreettinen viitekehyksemme on keskeisessä roolissa, sillä siitä riippuen vika ja vastuu painavat joko yksilön tai yhteiskunnan harteilla. Monet kriittiset teoriat, kuten intersektionaalisuus tai kriittinen rotuteoria, ovat tähän asti olleet harvinaisia suomalaisessa väestön moninaistumiseen liittyvässä terveys- ja hyvinvointitutkimuksessa. Kriittiset tulkinnat ovat kuitenkin tarpeen, sillä maahanmuuttoon ja terveyteen liittyvässä tutkimuksessa piilee etnosentrismin vaara (28), eli taipumus uskoa oman etnisen ryhmän paremmuuteen ja arvioida muita ryhmiä suhteessa omaan ryhmään. Oma tai ryhmämme sosioekonominen asema vaikuttaa myös merkittävästi siihen, miten asemoidumme rodullistetuissa yhteiskuntasuhteissa (15). Siinä, missä hyväosaisuuden ja eri kulttuurien kohtaaminen kuvataan usein positiivisesti kansainvälisyytenä, heikomman sosioekonomisen aseman ja kulttuurin risteyskohta nähdään monikulttuurisuutena. Tämän vuoksi monikulttuurisella koululla on toisenlainen kaiku kuin kansainvälisellä koululla.

Suomessa väestön moninaistumiseen liittyvät terveys- ja hyvinvointitutkimukset ovat tähän asti suurilta osin perustuneet poikkileikkausaineistoihin. Laajat haastattelututkimukset ovat sisältäneet paljon tietoa elinoloista ja -tavoista Suomessa, mutta vain yksittäisiä kysymyksiä entisestä kotimaasta. Kun nykyiset elinolot eivät selitä ryhmien välisiä eroja, jäljelle jäävät erot kuitataan helposti johtuvan kulttuurista tai "etnisyydestä". Kulttuuristen selitysmallien kanssa tulee kuitenkin olla erityisen tarkka, sillä rasistiset ideologiat ovat yhä enemmän koros- taneet kulttuurisia eroja ylittämättöminä esteinä ryhmien välillä (29). Tutkimustuloksia tulisi sen sijaan diskutoida enemmän elämänkulun kontekstissa. Yksi keino on sisällyttää uusiin aineistonkeruisiin retrospektiivisiä kysymyksiä varhaislapsuuden terveydestä ja elinoloista. Jos ohitamme varhaislapsuuden mahdollisen vaikutuksen aikuisiän terveyteen ja sosioekonomiseen asemaan, voimme päätyä virheellisiin johtopäätöksiin aikuisiän sosioekonomisen aseman ja terveyden välisestä yhteydestä (30).

Terveystieteissä tulisi myös rohkeammin tarkastella värillisyyttä, esimerkiksi värillisyyden roolia koetussa syrjinnässä ja sitä kautta terveysja hyvinvointieroissa. Tiedetään, että erityisesti omasta valkoisuudesta käsin, tutkijoiden voi olla vaikea tunnistaa rasismia ja ymmärtää sen vaikutuksia niiden elämässä, jotka rasismi sulkee valkoisen suomalaisuuden ulkopuolelle (15). Ymmärryksen puute valkoisuuden tuomasta hyödystä voi kuitenkin vääristää ja rajoittaa tulkintojamme väestöryhmien välisistä terveys- ja hyvinvointieroista. Aiempaa enemmän tulee myös tunnistaa, että näennäisesti neutraalit käytännöt johtavat syrjiviin lopputuloksiin, esimerkiksi työnhaussa (31). Avoimen rasistinen kohtelu sijoittuu usein yhteiskunnan laitamille, ja tämä on johtanut yleiseen harhaluuloon rasismin rajallisuudesta ja jopa harvinaisuudesta (27). Todellisuudessa rasismi on sisäänrakennettu moniin arkipäiväisiin tilanteisiin, mukaan lukien moniin vallitseviin tapoihin luokitella ihmisiä.

\section{KATSE TULEVAISUUTEEN}

Suomalaisuuden käsite kaipaa uudistamista, myös väestötutkimusten mukaan (13). Tutkijoilta toivotaan kannanottoja identiteettien moninaisuuden ja yhteiskunnallisen yhteenkuuluvuuden puolesta (23). Nykyinen maahanmuuttajuuden alleviivaaminen - niin tutkimuksessa kuin palvelujärjestelmässäkin - ylläpitää ja tuottaa leimoja ja toiseutta. Ulkomaalaistaustaisuuden eri tilastoluokitukset muuntuvat arkipäiväisessä ja poliittisessa retoriikassa yhdeksi sosiaaliseksi kategoriaksi, joka sijoitetaan kuvitellun kansallisen yhteiskunnan ulkopuolelle (32). Maahanmuuttajuuden ongelmallisuus on myös siinä, ettei sen oikeastaan nähdä päättyvän missään, eikä koskaan (33). Olemme aiheellisesti huolissamme huono-osaisuuden ylisukupolvisuudesta, mutta 
myös ulkopuolisuuden kokemus voi siirtyä sukupolvelta toiselle, jos jatkuvasti kyseenalaistamme Suomessa asuvien ja syntyneiden suomalaisuutta.

Suomen satavuotissyntymäpäivän kynnyksellä on syytä pysähtyä miettimään, kuka saa kutsua itseään suomalaiseksi? Ja kenellä on oikeus tämä määrittää? Suomen puolta pitävän nationalistisen näkökulman ei tarvitse olla nativistinen, joka rajaa ulkopuolelle kaikki transkulttuuriset juuret. Kuvitelma kulttuurisesti ja rodullisesti yhtenäisestä suomalaisuudesta on jo lähtökohtaisesti virheellinen ja vahingollinen myytti (34). Kasvava värillinen suomalainen väestö ja monet edelläkävijät kuten Ruskeat Tytöt tulevat muuttamaan valkoisuuden merkityksen suomalaisuuden määrittelijänä. Suomalaisuus tarvitsee kipeästi uuden määritelmän, joka ei syrjäytä, syrji tai sulje ulkopuolelle. Uudet avaukset ja näkökulmat vaativat monitieteellistä yhteistyötä, aikaa ajatella sekä altistusta uusille ajatuksille. Itse aloitin väitöskirjataipaleeni pohtimalla työhöni sopivinta maahanmuuttajakäsitettä, työn loppusuoralla olen valmis luopumaan koko käsitteestä. Miten rakennamme tutkimusperinteen, joka mahdollistaa väestön moninaisuuden tarkastelun, rajaamatta monia suomalaisia suomalaisuuden ulkopuolelle?

\section{KIITOKSET}

Kiitän Terveyden ja hyvinvoinnin laitosta, Kansainvälistä liikkuvuuden ja yhteistyön keskusta sekä Helsingin yliopistoa tutkijavaihtoni taloudellisesta tuesta. Kiitos erityisesti Irma Elolle, Ulla Buchertille ja Päivikki Koposelle puheenvuoroon liittyvistä kommenteista ja keskusteluista.

\section{LÄHTEET}

(1) Walters A, Brown HB, Williams HS, Du Bois WEB. To the Nations of the World. W. E. B. Du Bois Papers (MS 312). University of Massachusetts Amherst Libraries: Special Collections and University Archives; 1900.

(2) University of Pennsylvania. Facts and Figures. Luettu 20.4.2017. http://diversity.upenn.edu/ diversity_at_penn/facts_figures

(3) Zuberi T. Thicker Than Blood: How Racial Statistics Lie. Minneapolis: University of Minnesota; 2001.

(4) DeMott B. The Trouble with Friendship: Why Americans Can't Think Straight About Race. Yale: Yale University Press; 1998.

(5) Lee J, Bean F. Reinventing the Color Line Immigration and America's New Racial/Ethnic Divide. Social Forces 2007;86(2):561-586. https://doi.org/10.1093/sf/86.2.561

(6) Jones CP. Invited Commentary: "Race", Racism, and the Practice of Epidemiology. Am J Epidemiol 2001;154(4):299-304. https://doi.org/10.1093/aje/154.4.299

(7) Puuronen V. Rasistinen Suomi. Helsinki: Gaudeamus; 2011.

(8) Tervola J. Maahanmuutto lisännyt suosiotaan tutkimusaiheena. Kelan tutkimusblogi. 2016; Luettu 18.4.2017. http://blogi.kansanelakelaitos. fi/arkisto/3493

(9) Tilastokeskus. Käsitteet: Syntyperä ja taustamaa. Luettu 10.4.2017. http://stat.fi/meta/kas/ syntypera_ja_ta.html

(10) Poulain M. European migration statistics: Definitions, data and challenges. Teoksessa: Barni, M. \& Extra, G. (toim.) Mapping Linguistic Diversity in Multicultural Contexts Berlin/New York: Mouton de Gruyter; 2008. s. 43-66.

(11) Näre L. Migrancy, Gender and Social Class in Domestic Labour and Social Care in Italy: An Intersectional Analysis of Demand. J Ethnic and Migration Studies 2013;39(4):601-623. https://doi. org/10.1080/1369183X.2013.745238

(12) Huttunen L. Kasvoton ulkomaalainen ja kokonainen ihminen: marginalisoiva kategorisointi ja maahanmuuttajien vastastrategiat. Teoksessa: Jokinen A, Huttunen L, Kulmala A (toim.) Puhua vastaan ja vaieta. Neuvottelu kulttuurisista marginaaleista Helsinki: Gaudeamus; 2004.

(13) Larja L. Joka kolmas ulkomaalaistaustainen nuori samaistuu sekä suomalaisuuteen että taustamaahansa. Tieto\&trendit - Talous- ja hyvinvointikatsaus 2017.

(14) Helminen M. Pääseekö

"maahanmuuttajuudesta" ikinä eroon?. Tieto\&trendit-blogi. 2016; Luettu 10.4.2017. http://tietotrenditblogi.stat.fi//paaseekomaahanmuuttajuudesta-ikina-eroon/\#_ga=1.258 466570.164856898.1474025731

(15) Rastas A. Rasismi lasten ja nuorten arjessa. Transnationaalit juuret ja monikulttuuristuva Suomi. Akateeminen väitöskirja. Tampere: Tampere University Press; 2007.

(16) Thomas WI, Thomas DS. Situations Defined as Real are Real in their Consequences. Teoksessa: Stone GP, Farberman HA (toim.) Social Psychology Through Symbolic Interaction Massachusetts: Xerox College Publishers; 1970.

(17) Nieminen T, Sutela H, Hannula U (toim.) Ulkomaista syntyperää olevien työ ja hyvinvointi Suomessa 2014. Helsinki: Tilastokeskus; 2015. 
(18) Brubaker R. Ethnicity, Race, and Nationalism. Annu Rev Sociol 2009;35:21-42. https://doi.org/10.1146/annurevsoc-070308-115916

(19) Castaneda A, Rask S, Koponen P, ym. (toim.) Maahanmuuttajien terveys ja hyvinvointi

- Tutkimus venäläis-, somalialais- ja

kurditaustaisista Suomessa. Raportti 61. Helsinki: THL; 2012.

(20) Wikström K, Haikkola L, Laatikainen T. Maahanmuuttajataustaisten nuorten terveys ja hyvinvointi. Tutkimus pääkaupunkiseudun somali- ja kurdistaustaisista nuorista. Työpapereita 17. Helsinki: THL; 2014.

(21) Matikka A, Luopa P, Kivimäki H, ym. Maahanmuuttajataustaisten 8 . ja 9 . -luokkalaisten hyvinvointi. Kouluterveyskysely 2013. Raportti 26. Helsinki: THL; 2014.

(22) Smith BR. Hyphen-Nation. 2017; Viitattu 15.4.2017. https://www.nytimes.com/interactive/ projects/storywall/hyphen-nation

(23) Tiilikainen M, Ismail A, Tuusa E, Abdulkarim M, Adam A. Somalis in Helsinki. New York: Open Societies Foundations; 2013.

(24) Mahmoud NJ. Twisting identity and belonging beyond dichotomies. The case of second generation female migrants in Norway. Münster: LIT Verlag; 2013.

(25) Bhopal R. Glossary of terms relating to ethnicity and race: for reflection and debate. J Epidemiol Community Health 2004 Jun;58(6):441-445. https://doi.org/10.1136/jech.2003.013466

(26) Andreassen KK, Dzamarija MT, Slaastad TI. Large diversity in little Norway. Immigrants and Norwegian-born to immigrant parents population statistics. Samfunnsspeilet 2013;5.

(27) Ford CL, Airhihenbuwa CO. The public health critical race methodology: Praxis for antiracism research. Soc Sci Med 2010 10;71(8):13901398.
(28) Bhopal RS. Migration, Ethnicity, Race, and Health in Multicultural Societies. 2. painos. Oxford: Oxford University Press; 2013.

(29) Makkonen T. Syrjinnän vastainen käsikirja. Helsinki: International Organization for Migration; 2003.

(30) Elo IT. Social Class Differentials in Health and Mortality: Patterns and Explanations in Comparative Perspective. Annu Rev Sociol 2009;35:553-572.

https://doi.org/10.1146/annurevsoc-070308-115929

(31) Liebkind K, Larja L, Brylka A. Ethnic and Gender Discrimination in Recruitment: Experimental Evidence From Finland. 2016;4(1):403-426.

(32) Elrick J, Farah Schwartzman L. From statistical category to social category: organized politics and official categorizations of 'persons with a migration background' in Germany. Ethnic and Racial Studies 2015;38(9):1539-1556. https://doi.org/10.1080/01419870.2014.996240

(33) Buchert U. Maahanmuuttajuuden institutionaaliset kategoriat. Kuntoutussäätiön tutkimuksia 87. Akateeminen väitöskirja. Helsinki: Kuntoutussäätiö; 2015.

(34) Tervonen M. Historiankirjoitus ja myytti yhden kulttuurin Suomesta. Teoksessa: Markkola P, Snellman H, Östman A, (toim.) Kotiseutu ja kansakunta. Miten suomalaista historiaa on rakennettu. Helsinki: Suomalaisen Kirjallisuuden Seura; 2014. s. 137-162.

\section{SHADIA RASK \\ TtM, tutkija, tohtorikoulutettava \\ Terveyden ja hyvinvoinnin laitos}

